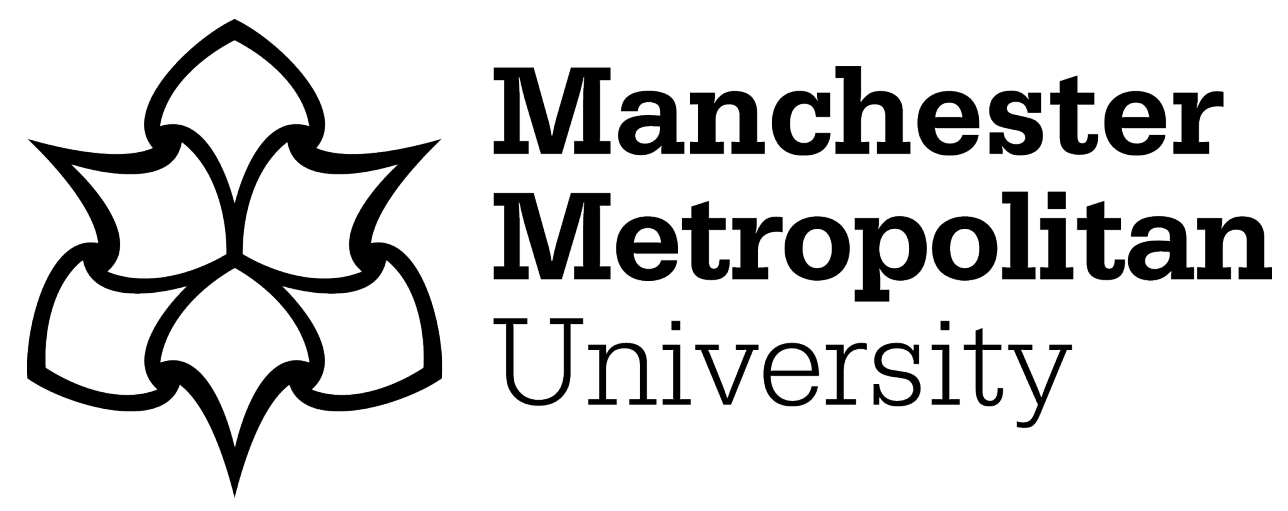

Abdallah, A, Anchor, J, Papalexi, Marina and Dastgir, Shabbir (2022) Organisational Performance and the Use of Multiple Performance Measures in an Emerging Market. International Journal of Quality and Reliability Management, 39 (1). pp. 236-257. ISSN 0265-671X

Downloaded from: https://e-space.mmu.ac.uk/627414/

Version: Accepted Version

Publisher: Emerald

DOI: https://doi.org/10.1108/IJQRM-04-2019-0107

Usage rights: Creative Commons: Attribution-Noncommercial 4.0

Please cite the published version 


\section{eneala PUBLISHING \\ International Journal of Quality \& Reliability Manag}

\section{Organisational performance and the use of multiple performance measures in an emerging market}

\begin{tabular}{|r|l|}
\hline Journal: & International Journal of Quality \& Reliability Management \\
\hline Manuscript ID & IJQRM-04-2019-0107.R2 \\
\hline Manuscript Type: & Quality Paper \\
\hline Keywords: & $\begin{array}{l}\text { Multiple performance measures, financial performance measures, non- } \\
\text { financial performance measures, organisational performance, Libya }\end{array}$ \\
\hline Abstract: & \\
\hline
\end{tabular}

\section{SCHOLARONE \\ Manuscripts}




\title{
Organisational performance and the use of multiple performance measures in an emerging market
}

\begin{abstract}
Purpose: This study is an empirical investigation of the relationship between the use of 41 multiple performance measures (MPMs), including financial performance measures (FPM), non- financial performance measures (NFPMs), and organizational performance (OP) in Libya.

Design/methodology: The results are based on cross-sectional questionnaire survey data from 132 Libyan companies (response rate 61\%), which were obtained just before the so called Arab Spring.
\end{abstract}

Findings: MPMs are used by both manufacturing and non-manufacturing companies. Libyan business organizations are more likely to use FPMs than NFPMs. However, these companies still rely more heavily on FPMs. The relationships between the use of NFPMs and OP and the use of MPMs and OP are positive and highly significant. The relationship between the use of FPMs and OP is positive but not significant.

Research limitations/implications: The high power distance associated with the conservative, Libyan, Arab context will reinforce the tendency to use FPMs more than NFPMs. This may provide a performance advantage to those organizations which do adopt NFPMs.

Practical implications: Although there may be institutional barriers to the use of NFPMs in Libya, and other emerging markets, these are not insuperable and there is a payoff to their use.

Originality/value: No previous studies of emerging markets, such as the Middle East or North Africa, have looked at the relationship between OP and the adoption of such a large array of MPMs.

Keywords Multiple performance measures; financial performance measures; non-financial performance measures; organisational performance; Libya.

\section{Research paper}




\section{Introduction}

A wealth of studies and reviews have identified that performance measurement is essential in order for organisational strategic goals to be implemented and a competitive advantage to be achieved and sustained (Abidi et al., 2014; Melnyk et al., 2014; Nawaz and Haniffa, 2017; Scarpin and Brito, 2018). Performance measurement systems (PMS) act as a catalyst for translating strategy into measurable objectives (Chatha and Butt, 2015; Micheli and Mura, 2017; Pollanen et al., 2017). A performance measurement system represents a comprehensive set of performance indicators used to quantify the efficiency and effectiveness of organisations' operations (Busco and Quattrone, 2015; Stålberg and Fundin, 2016). Performance indicators enable an organisation to "convey the strategy to everyone else in terms they can understand, thus making the strategy concrete and meaningful" as Melnyk et al. $(2014,173)$ reported. These metrics can be financial or non-financial, short or long term, internal or external (Neely, 2011; Santos et al., 2012). The most common typology is a division into financial performance measures (FPMs) and non-financial performance measures (NFPMs).

There has been considerable research, on the move from so-called "conventional, traditional or financial" measures to more wide-ranging "non-financial, innovative, integrated, balanced or multiple" measures, which has been a key development in the performance measurement field (Garengo and Sharma, 2014; Cooper and Ezzamel, 2013; Kasperskaya and Tayles, 2013; Ittner et al., 2003; Bourne et al., 2000). Well-defined performance indicators direct organisations to achieve desired performance. However, the key characteristics of effective performance measurement systems remain unclear (Saunila et al., 2017). There are unresolved issues relating to the role of NFPMs in strategic performance and management frameworks, particularly in relation to motivation, ability and long-term firm value (O'Connell and O’Sullivan, 2014). An effective performance measurement system may be based on using a balanced set of key financial and non-financial critical success factors and key performance indicators, which stimulate involvement in continuous improvement (Andrews and Wulfeck, 2014). NFPMs and FPMs could both shape the PMS of organisations by using data on objective and subjective measures of performance, covering different parts of an organisation's operations (Brouthers, 2013; Wu and Liao, 2014; Singh et al.,2016). Indeed, there is a need for empirical research to examine to what extent the inclusion of both financial and non-financial indicators is more effective in enhancing organisational performance (Dossi and Patelli, 2010; Upadhaya et al., 2014; Micheli and Mura, 2017). 
This research draws on two bodies of literature - one that has explored the relationship between the use of MPMs and organisational performance; and one that has evaluated the use of MPMs and their impact on the Libyan emerging market setting. A regression analysis was conducted to analyse the quantitative data collected from 141 Libyan companies in a variety of industries (manufacturing and non-manufacturing). This study makes two main contributions to theory and practice. First of all, the paper contributes to the existing literature by identifying the relationship between the use of MPMs and organisational performance. Organisational performance may, at least in part, depend on the diversity of performance measures used. This means that a company may achieve superior performance when it uses a broad range of financial and non-financial performance measures (Asiaei and Jusoh, 2014). The studies on organisational performance have used a variety of performance indicators focusing on either the public (e.g. Liguori et al., 2012; Pollanen et al., 2017) or manufacturing sectors (Sidin and Wafa, 2014; Maletic et al., 2015). However, there is a need for empirical investigation to be conducted in order to ascertain and validate the existing findings.

The second contribution of this research is related to the adoption of MPMs in the Libyan emerging market setting. Multiple performance measures (MPMs), such as quality, productivity, innovation and customer satisfaction, have received a lot of attention from practitioners and academics since the early 1990s, particularly in developed economies. The much smaller number of studies in emerging market contexts has failed to provide clear evidence about the effectiveness of MPMs (Tjader et al., 2014; Henri, 2004, 2006). The awareness and utilisation of NFPMs and MPMs is likely to be lower in an emerging market than in more advanced economies. Since institutions generally are less developed in emerging markets than in advanced economies (Khanna and Palepu, 2000), it is to be expected that there will be less familiarity with non-financial data and with "newer" measures of organisational performance.

The study finds that NFPMs are used to a significant extent by Libyan companies across different industries; however, FPMs are used more widely than NFPMs and MPMs. In other words, the Libyan companies surveyed in this research tend to rely on traditional (financial) measures more than multiple measures for evaluating their performance. The use of NFPMs and MPMs has a significant positive effect on Libyan companies' performance. A positive, 
but not significant, effect was found in the case of FPMs. Therefore, measurement diversity is found to have a positive effect on organisational performance.

The paper is structured as follows. The next section provides a comprehensive literature review of the links between MPMs and organisational performance. It also discusses research on the impact of MPMs on company performance operating in emerging market contexts. Subsequently, the quantitative data analysis is presented in section 3. Section 4 outlines and discusses the research findings, examining the main contributions to theory and practice. The conclusions, limitations and avenues for further research appear in Section 5.

\section{Literature Review, Research Questions and Hypotheses Development}

\section{MPMs and organisational performance}

Organisations need to embrace different strategic approaches to survive and compete with powerful new players entering the marketplace (Nawaz and Haniffa, 2017). Scholars focusing on this research area underpin the existence of different strategic approaches that trigger the use of diverse types of performance indicators (Lopes et al., 2016; Micheli and Mura, 2017; Vallurupalli and Bose, 2018). Indeed, a cost-leadership strategy is tightly intertwined with the use of financial performance measures (FPMs). On the other hand, multiple performance measures (MPMs), both financial performance measures (FPMs) and non-financial performance measures (NFPMs), are utilised by differentiation strategies (Porter 1980; Homburg et al., 2012; Bourne et al., 2013).

Most organisations use FPMs because they are indicators of firms' profitability, performance, cost reduction and cash flow (Kim and Pennington-Gray, 2017; Agyei-Mensah, 2017). Merchant and Van der Stede (2007) explained that FPMs ensure the organisation's survival; provide a comprehensive measure of performance; are relatively precise and objective; and have wide applicability. However, they have also summarised the criticisms of the use of financial measures, stating that FPMs are numeric data that represent a certain period without taking into consideration factors that do not result in a transaction or cannot be measured accurately and objectively. He and $\mathrm{Lu}$ (2018) reiterated this by explaining that financial measures cannot incorporate the valuation of the company's intangible and intellectual assets. Similarly, Anil and Satish (2019) stated that although most organisations use customer satisfaction and cost to measure their performance, the development of other performance 
indicators, such as quality, will support organisations to outperform others in the competitive environment. Li et al. (2017) and Fakhri et al. (2009) explained that changes in a business environment, such as increased competition and technological advances, are another reason for the inadequacy of financial measures.

The potential importance of including both financial and non-financial indicators to enhance operational performance has become a developing research area (Dossi and Patelli, 2010; Upadhaya et al., 2014). Yuliansyah et al. (2017) found that the adoption of a differentiation strategy leads to the development of superior performance and the achievement of competitive advantage. Similarly, Spencer et al. (2009) considered only firms pursuing a differentiation strategy and found a positive association between strategy and organisational performance using mainly non-financial indicators. Hussain et al. (2018) and Gómez-Bezares et al. (2017) argued that social and environmental indicators play a critical role in achieving manifold performance objectives and adopting sustainability performance. Maletic et al. (2015) concluded that the use of non-financial performance indicators, including operational performance, innovation performance, employee performance, environmental performance, customer performance and economic performance, measure effectively the organisational performance of manufacturing companies. In a similar vein, Sidin and Wafa (2014) found that Malaysia's manufacturing companies could improve their organisational performance though the use of a multidimensional construct, which considers leadership, employee participation, customer satisfaction, data analysis, process management and organisational culture. Liguori et al. (2012) stated that public organisations consider that NFPMs provide more meaningful information than FPMs; multiple aspects of public-sector performance cannot be measured taking into account only financial measures (Pollanen et al. 2017). Studies have showed that indicators of efficiency, effectiveness, responsiveness, and equity have a positive association with organisational performance and contribute to the enhancement of service quality (Andrews and van de Walle, 2013; Elbanna et al., 2015).

Although there is widespread interest in diverse performance measurement systems (e.g. BSC), few empirical studies have looked directly at the effectiveness of the deployment of MPMs (Wellens and Jegers, 2014; Androwis et al., 2018). Indeed, the association between the deployment of MPMs and organisational performance has been found to be inconsistent in a number of previous studies (Upadhaya et al., 2014; Agyei-Mensah, 2017; Yuliansyah et al., 
2017). Some have found a positive relationship between the use of multiple performance measures and organisational performance (Stede et al., 2006; Fleming et al., 2009; Akgun et al., 2014). However, other studies have provided contradictory evidence (Ittner et al., 2003; Braam and Nijssen, 2004; Neely, 2008).

In summary, it is unclear if there is a positive association between the use of MPMs and organisational performance. Some researchers have found convincing evidence of a positive relationship between both variables. Others have found that the use of performance measurement diversity might not be associated with enhanced organisational performance. As a result, this research aims to extend the existing literature by focusing on both the public and manufacturing sector and to re-investige the relationship between the use of multiple performance measures and organisational performance in a new, emerging market, setting. Therefore, the following hypotheses were developed, based on the preceding literature review: H1: Organisational performance is negatively associated with the use of traditional (financial) performance measures.

H2: Organisational performance is positively associated with the use of non-financial performance measures.

H3: Organisational performance is positively associated with the use of multiple performance measures.

\section{The adoption of MPMs in an emerging market}

A fundamental difference between emerging and developed market economies is the existence in the latter of market supporting formal institutions (Alvi, 2012). Formal institutions include a country's laws and regulations. Informal institutions include the norms and values which are derived from a country's culture, language and society (Dikova et al., 2010). Institutions formal and informal - provide "rules of the game" in an economy (North, 1990). The distinction between emerging and developed market economies is not an exact dichotomy however and a particular economy may display both emerging and developed market characteristics at any given point in time. Moreover, emerging markets are themselves not homogeneous and may display a variety of institutional contexts (Djankov and Murrell, 2002; Peng, 2003; Wright et al., 2005; Hosskisson et al., 2013; Wu, 2013). However, as emerging markets evolve, institutional structures tend to move from relationship based personal exchanges to those which are rule based and impersonal with third party enforcement. 
Libya, the emerging market from which data was collected, is an Arab country. Therefore, its culture, management systems, and business environment need to be seen within an Arab context. Its politics, economy, and culture are all based on tribalism, Islam, and a lack of a democratic political culture (Al-Rasheed, 2001). Libya is also characterised by high power distance, high collectivism and high uncertainly avoidance (Hofstede et al., 2010). These historical tendencies were re-inforced by the idiosyncratic nature of the Gadaffi regime, which was forced from power in 2011 (Pargeter, 2012). The nature of the regime and its isolation from the world acted as a barrier to the diffusion of management best practice. All of these features may lead to a preference for the use of, so called, hard data and the financial performance measures which make use of them. Furthermore, extant literature indicates that there is a need for an extended scholarly attention in the area of performance management (Posthuma, 2011) in this emerging market (Iles et al., 2012; Abdelzaher et al., 2017).

The second aim of this paper is to identify the type of financial and non-financial performance measures adopted by Libyan business organisations. A number of studies have addressed this issue in other geographical contexts (Neely, 2008; Yongvanich and Guthrie, 2009; Lau and Roopnarain, 2014). The majority of these studies have been conducted in a manufacturing setting and in developed countries, especially the USA, UK and Australia. Only a few of them have been conducted in non - manufacturing settings and/or emerging economies (Yongvanich and Guthrie, 2009; Ismail, 2007). There has been significant research in Libya focusing on the banking industry (Musbah et al., 2016; Agley-Mensah, 2017; Elnihewi et al., 2017); quality management (Abusa and Gibson, 2013; Ahmad and Elhuni, 2014); asset management (Beitelmal et al., 2017); healthcare management (Imhmed et al., 2014) and marketing performance (Elkrghli, 2017). The use of financial measures is still of great importance to most companies in both developing and developed countries (Mintz and Currim, 2013; Al Sawalqa, 2011; Fakhri, 2010; Neely, 2008; Ismail, 2007). However, the use of multiple performance measurement systems remains uneven, particularly in emerging market contexts (Wei et al., 2014). To fill this research gap, the following questions were posed:

What is the extent of the adoption of multiple performance measures by Libyan companies? Do Libyan companies place a greater emphasis on using traditional (financial) measures, rather than MPMs, in evaluating their performance? 


\section{Research Method}

\subsection{Sample and Research Strategy}

The population of this research was defined as all Libyan companies, manufacturing and nonmanufacturing, whether small, medium or large, except for: new companies with little experience (less than three years of age) and very small companies (less than 10 employees). Since respondents were asked to describe selected research variables during the previous three years, very new companies were not suitable. In addition, earlier studies have indicated that the use of management accounting and financial performance measures within small companies is generally very low (Michalski, 2014; Verbeeten and Boons, 2009; Chenhall, 2003; Hussain and Hoque, 2002 and Hoque and James, 2000). The sampling frame consisted of 226 Libyan companies in a variety of industries (76 manufacturing and 150 nonmanufacturing). Only headquarters were included, in order to obtain a more homogenous sample; subsidiaries, divisions and branches were excluded. The data collection was completed just before the revolution in Libya, which overthrew the Gadaffi regime, and the ensuing civil war.

Data was collected using a self-administered survey questionnaire. The questionnaire survey targeted finance directors, vice-financial managers, financial controllers and senior accountants because they are responsible for designing and operating the performance measurement systems in their companies (MacBryde et al., 2014; Verbeeten and Boons, 2009; Chenhall and Langfield-Smith, 1998).

The questionnaire was divided into three main parts. All three parts included closed questions, i.e. all the questions had a range of potential answers and the respondents had to select one of them. The first part consisted of questions concerning general information about the characteristics of participants and their organisations. The second and third parts were concerned with the independent and dependent variables of the study. In these parts, the questions were based on a 5-point Likert scale. 226 questionnaires were distributed and 141 were returned. 132 questionnaires were usable and valid for analysis (which represents a $61 \%$ response rate). This is a good rate compared with other similar studies (Micheli and Mura, 2017; Koufteros, 2014; Salleh et al., 2010; Mia and Winata, 2008 and Hoque, 2004).

\subsection{Demographic Profiles of Respondents and Organisations}


It is clear that a large majority of the managers who responded to the survey were experienced $-60 \%$ had been in their current job more than 10 years. More than $80 \%$ had at least a Bachelor degree and more than $70 \%$ had their main qualifications in accounting or finance.

Table 2 presents the key characteristics of respondent companies. It covers six main features: the age of the company, the main type of industry, company size (in terms of number of employees and annual revenue) and ownership type.

\section{$<$ please insert Table 2 here $>$}

Most companies were state owned and had been established for 20 or more years. More than 60 per cent were small or medium sized. This relationship between size and ownership is different from that which has been typically found in earlier studies which, as was noted earlier, have been conducted predominately in developed, and Western, countries.

\subsection{Measurement of Variables}

During the preparation of measures and constructs for the research variables, any terms or measures, which were specific to a particular sector were excluded in order to make the questionnaire applicable to all sectors (manufacturing and non-manufacturing). The conceptual definitions of these variables are provided in the next sub-sections. 
The use of multiple performance measures (MPMs) refers to the extent to which managers utilise a broad scope of information, derived from financial and non-financial measures, for assessing performance. This approach was spilt into five major categories which are commonly used by both manufacturing and service organisations. The first four categories were adapted from the studies of Jusoh (2010); Bento and White (2010); Salleh et al., (2010); Ismail (2007); Van der Stede et al., (2006); Henri (2006); Hoque (2004, 2005); Bryant et al., (2004); Ittner et al., (2003); Hoque and James (2000) and Scott and Tiessen (1999), which are based on the work of Kaplan and Norton (1992). The fifth category (community/environment perspective) was modified from the work of Fakhri (2010); Youssef (2007); Yaghi (2007) and Zuriekat (2005). The instrument includes 41 different measures ${ }^{1}$. The respondents were requested to indicate on a five-point Likert-type scale ranging from 1 (not used at all) to 5 (used considerably), the extent of their organisation's use of the identified performance measures over the previous three years. The responses to a scale ranging from "not used at all" to "used considerably" with a neutral response of "used moderately" in the middle, may be considered to be equivalent to providing a 'yes' or 'no' and a confident response (the strength or confidence of measurement in this scale is assessed as the distance away from the neutral response) (Horenbeek and Pintelon, 2014; Youssef, 2007; Fakhri, 2010).

Organisational performance (OP) refers to the extent to which the organisation is successful in achieving its planned targets or stated aims (Pinhoet al., 2014; Mia and Clarke, 1999). It is described as the ultimate outcome variable (dependent variable) in the contingency literature because it explains the implications of a fit between control systems design and other organisational characteristics of a company. It was assessed by a self-rating multiple instrument. The scale included 13 items developed originally by Govindarajan (1984) and used subsequently in several studies (Van der Stede et al., 2006; Hoque 2004, 2005 and Chong and Chong, 1997). Respondents were required to rate each of the 13 dimensions on a five-point Likert-type scale, ranging from 1 (poor) to 5 (outstanding), to assess their organisation's performance compared to that of their main competitors over the previous three years. The organisational performance score for each organisation was calculated by taking the mean for all items (Dusterhoff et al., 2014; Hoque, 2005) and it is shown in Table 3.

\footnotetext{
${ }^{1}$ Firstly, the extent of FPMs usage is the overall mean of responses for the first 11 measures. Secondly, the other 30 measures were selected to measure NFPMs' usage. Thirdly, the extent of MPMs usage is the overall mean of responses to all 41 measures.
} 
$<$ please insert Table 3 here $>$

\subsection{Analytical procedures}

The instrument was assessed by a pilot study and a reliability test. Specifically, the results indicate (Table 4) that the Cronbach's alpha coefficients of all the variables were above the minimum acceptable level of 0.60: multiple performance measures usage (0.919); financial performance measures usage (0.767); non-financial performance measures usage (0.939); and organisational performance $(0.800)$. An assessment of normality was performed for the dependent variable only (Bakker et al., 2014; Field, 2005). The Kolmogorov-Smirnov test was used to evaluate the normality of the dependent variable (organisational performance). The findings confirm that the dependent variable follows a normal distribution ${ }^{2}$. The relationship between the use of MPMs and organisational performance was identified by simple regression analysis.

\section{$<$ please insert Table 4 here $>$}

\section{Results and Discussion}

This section, initially, deals with the testing of the three hypotheses of the first research objective (H1-H2-H3) and assesses the nature and type of direct relationships between the use of financial performance measures, non-financial performance measures, multiple performance measures, and organisational performance. The statistical technique employed for testing these hypotheses was simple regression analysis. Subsequently, this section presents and discusses the descriptive statistics relating to the second research objective, which is the status and extent of the use of MPMs among Libyan companies.

\subsection{Testing the relationship between the use of MPMs and organisational performance}

Traditional (financial) performance measures (FPMs), non-financial performance measures (NFPMs) and multiple performance measures (MPMs) were employed as independent

\footnotetext{
${ }^{2}$ The Kolmogorov-Smirnov test reports the following results: Statistic (.078), df (.132) and Sig. (.059).
} 
variables (predictors), with organisational performance (OP) as a dependent variable in all three models respectively. Table 5 presents the findings of the regression analysis concerning these hypotheses (H1-H2-H3).

$<$ please insert Table 5 here $>$

The effect of FPMs on organisational performance was positive; however, it is not statistically significant $\left(\mathrm{R}^{2}=.011, \beta=.107, \mathrm{p}>.05\right)$. Hypothesis $\mathrm{H} 1$ was not supported at the .05 significance level; therefore, it is rejected. It can be concluded that the use of FPMs has no significant impact on the performance of Libyan organisations (H1). This result is in line with that of most previous research (e.g. Gharbal et al., 2014; Van der Stede et al., 2006 and Ittner et al., 2003). Although we hypothesised that using FPMs alone in the Libyan business environment would influence negatively organisational performance, this does not mean that FPMs are not important. Most authors contend that FPMs are still crucial in assessing performance in any organisation, as they are necessary in order to track revenue, profit and costs (Kim and Pennington-Gray, 2017; Agyei-Mensah, 2017; Kang and Montoya, 2014; Kaplan and Norton, 1992). Micheli and Mura (2017) and Singh et al., (2016) explained that organisations adopt different strategic approaches that require the use of diverse types of performance indicators. Indeed, Henri (2004) argued that NFPMs do not have to replace FPMs. Rather it is better to supplement FPMs with a diverse set of NFPMs that are believed to provide better information and contribute to improving organisational performance. Scarpin and Brito (2018) considered quality as a foundation capability that assists organisations to achieve improved performance; however they suggested that measuring financial performance is still important as quality does not always lead to a reduction in cost. Agyei-Mensah (2017) and Lingle and Schiemann (1996) argued that leading organisations utilise both FPMs and NFPMs to enhance their performance and develop their strategies. Franco-Santos, Lucianetti and Bourne (2012) highlighted the importance of NFPMs, along with core FPMs, and their positive impact on organisational performance. There is widespread recognition that the development of a differentiation strategy that considers both financial and non-financial indicators has a positive impact upon operational performance, thereby providing a competitive advantage (Yuliansyah et al., 2017; Nawaz and Haniffa, 2017). 
The impacts of both NFPMs and MPMs on organisational performance are positive and statistically highly significant $\left(\mathrm{R}^{2}=.218, \beta=.467, \mathrm{p}<.05 ; \mathrm{R}^{2}=.222, \beta=.471, \mathrm{p}<.05\right.$ respectively). Hypothesis $\mathrm{H} 2$ was supported at the .05 significance level; therefore, it is accepted. One explanation for the positive results regarding the NFPMs-OP relationship (H2) is that the NFPMs are future-oriented measures. This is also supported by the research conducted by Spencer et al. (2009). Hence, top management tries to rely heavily on these measures in making decisions that will be useful to their organisations in the long run (Yuliansyah et al., 2017; Pollanen et al., 2017; Saunila et al., 2017; O’Connell and O'Sullivan, 2014; Chenhall and Langfield-Smith, 2007). Upadhaya et al., (2014) and Hoque (2004) concluded that the use of non-financial indicators, including leadership, organisational culture, employee performance, customer satisfaction and process management, is tightly intertwined with organisational effectiveness.

It is clear from the results above that MPMs introduce valuable diverse information, which contributes to improving business performance (Andrews and van de Walle, 2013; Elbanna et al., 2015). This suggests that the more extensively MPMs are used, the better the organisational performance. Hypothesis H3 was supported at the .05 significance level; therefore, it is accepted. This indicates that relying solely on FPMs is not sufficient to enhance company performance. The significant and positive findings in relation to $\mathrm{H} 3$ are consistent with most previous research, which finds that the use of the combination of FPMs and NFPMs is positively associated with organisational performance (Androwis et al., 2018; Ho et al., 2014; Al-Sawalqa, 2011; Jusoh, 2010; Yongvanich and Guthrie, 2009; Fleming et al., 2009; Govindarajan and Gupta, 1985; Hoque and James, 2000; Zuriekat, 2005; Van der Stede et al., 2006; Bryant et al., 2004). Vallurupalli and Bose (2018) and Micheli and Mura (2017) found that the use of different types of performance indicators positively impact upon innovative performance. Eklof et al. (2017) stated that measuring customer satisfaction, which is a NFPM, enhances organisations' financial performance.

On the other hand, the results in relation to $\mathrm{H} 3$ contrast with others, which have found no evidence for the proposition that measurement diversity is positively associated with organisational performance (Ittner and Larcker, 1998; Ittner et al., 2003; Braam and Nijssen, 2004; Hoque, 2005; Franco-Santos, 2007; Neely, 2008).

\subsection{The Extent of the Use of MPMs}


Table 6 summarises the responses relating to the extent to which the 41 performance measures are used within Libyan companies across different industries. The results show that MPMs have widespread use; however, a comparison of the mean scores among performance measures indicates, as expected, that the extent of the use of FPMs is greater (mean $=3.88$ ) than for NFPMs and MPMs, which have mean values of 3.52 and 3.62 respectively. Most prior studies conducted in emerging market contexts have found that many companies use MPMs (financial and non-financial) but to different extents (Abdelzaher et al., 2017; Upadhaya et al., 2014; Al Sawalqa, 2011; Fakhri, 2010; Ismail, 2007; Youssef, 2007 and Hutaibat, 2005). Fakhri (2010) found that although Libyan banks used FPMs more extensively, they use a variety of NFPMs to ensure the accuracy and validity of their outputs. Elnihewi et al. (2018) also highlighted the importance of using MPMs in the Libyan service industry. Abdelzaher et al., (2017) stated that employee engagement is significantly associated with organisations' survival in Muslimmajority markets.

\section{$<$ please insert Table 6 here $>$}

The results of the descriptive statistics for all 11 FPMs show that except for the last two financial measures (EVA and MVA), all other financial measures were ranked as "used significantly" or "used considerably" by more than $70 \%{ }^{3}$ of the participating companies, with means ranging from 4.06 to 4.43. As can also be seen in this table, EVA and MVA measures were not used frequently - they were the only financial measures to be used less than average (under "used moderately", 3) among Libyan companies as they have mean scores of 2.42 and 2.39 respectively. A possible explanation for this is that, as earlier research has concluded, recently developed accounting measures, such as EVA, have been criticised as being complex, difficult to use and understand, costly and not superior to traditional accounting measures (Chiwamit et al., 2014; Ittner and Larcker, 1998). These limitations may be one of the reasons for the low usage of these measures among Libyan companies. However, the fact that institutions in emerging markets such as Libya are less developed than in more mature markets is likely to lead to there being less trust in other measures, especially those which rely on non-

\footnotetext{
${ }^{3}$ To describe the levels of significance rates of all performance measurement groups (financial and non-financial), they were counted as the respondents' answers for the equivalent answers of 4 and 5 in their companies.
} 
financial data or on government data. Meier and O'Toole (2013) suggested that the use of NFPMs might lead to inaccurate performance assessment as they tend to overestimate organisational performance. Singh et al. (2016) and Elnihewi et al. (2018) stated that some organisations, especially in developing countries such as Libya, are not able to collect consistent and reliable non-financial data. The high power distance associated with Libyan society is more likely to lead to the use of FPMs which require "hard" data.

The descriptive statistics shown in Table 6, concerning non-financial measures, suggest that respondents ascribed the highest score to the usage of customer perspective-based PMs, followed by internal operations-based PMs and innovation and learning - based PMs, while environmental and community-based PMs were the least used by Libyan companies. Customer satisfaction was the most commonly used non-financial measure of performance evaluation. By contrast, the results indicate that the community regulations-based measure was not a popularly used non-financial measure of performance evaluation; it was used by only $34.8 \%$ of the respondent companies with a mean of 2.43. This result was similar to that of Ismail (2007) who found evidence that customer satisfaction was the most commonly used nonfinancial performance measure in an Egyptian setting. One possible explanation for this is that most decision-makers in the Libyan companies studied might be unaware of the potential importance of environmental and community-based measures in improving the performance of their companies (Ahmad and Mousa, 2010).

The findings shown in Table 6 indicate that the use of customer-based PMs is quite common among Libyan companies (mean =3.76). Market share (3.95) and customer satisfaction (4.05) are measures commonly used by Libyan companies. Both customer retention measures and ontime delivery (product/service) measures were ranked as "used significantly" or "used considerably" by $67.4 \%$ of companies. Furthermore, a number of customer compliances and customer service levels ${ }^{4}$ were ranked by $65.9 \%$ of the participating companies, while customer loyalty and customer response time seem to be used to a moderate extent as they were ranked as "used significantly" or "used considerably" by $62.8 \%$ and $56.8 \%$ of the respondent companies. These results are in line with Jusoh and Parnell (2008) who found that the use of customer measures such as on-time delivery, survey of customer satisfaction and number of

\footnotetext{
${ }^{4}$ To describe the levels of significance rates of all performance measurement groups (financial and non-financial), they were counted by the respondents' answers for the equivalent answers of 4 and 5 in their companies.
} 
customer complaints was high among Malaysian manufacturing companies. Similar results were found by Gosselin (2005).

It can be seen from Table 6 that Libyan companies place a similar emphasis on the use of both internal business process-based PMs (mean = 3.56) and innovation and learning-based PMs (mean $=3.53$ ). For the first category, productivity was at the top of the list because it was ranked as "used significantly" or "used considerably" by $67.5 \%$ of respondents. There were two other measures - cost savings and defects rate of product/service - which were ranked by a similar percentage $(62.1 \%)$ of the participating companies. Product/service quality, product/service development, safety, cycle time/lead times (product/service) were ranked as "used significantly" or "used considerably" by 60.6\%, 57.6\%, 55.3\% and 56.1\% respectively. Innovation and learning-based PMs appear to be used to a moderate extent as they all were ranked as "used significantly" or "used considerably" by between $57.6 \%$ and $52.3 \%$ of the respondent companies.

Finally, the results indicate that environment and community-based PMs are the least used measures among Libyan companies compared to the other four types of PM. Public image was ranked first among these measures - being reported by $65.2 \%$ of respondents as "used significantly" or "used considerably". The findings indicate that $52.2 \%$ of the respondent companies use environmental commitment-based PMs and 55.3\% of them use community involvement-based PMs, whereas measures based on support of charity projects, support of social activities and government citations perspectives were at the bottom of this list as they were ranked as "used significantly" or "used considerably" by $34.8 \%, 36.4 \%$ and $39.4 \%$ respectively. By contrast, community regulations-based PMs were not commonly used by Libyan companies since they have a usage rate of only $34.8 \%$.

To sum up, MPMs are commonly used by Libyan companies. However, they tend to place a greater emphasis on traditional (financial) measures (mean $=3.88$ ) than on multiple measures (3.62), in evaluating their performance, although organisations are aware of the benefits and importance of measurement diversity in serving their needs and purposes. A possible explanation for the above result is that the implementation of innovative information systems and techniques (ABC, BSC, etc.) is difficult in emerging markets due to the lack of appropriate infrastructure (Peasnell, 1993). There are also institutional barriers to their adoption since, as was noted earlier, the idiosyncratic nature of the Gadaffi regime and its isolation from the world generates difficulties in adopting best management practices (Pargeter, 2012). All of these 
features may lead to a preference for the use of so called, hard data and the financial performance measures which make use of them. In fact, it is perhaps surprising that the preference for FPMs is not greater.

\section{Conclusions}

This study has examined the relationship between the use of MPMs and organisational performance and evaluated the use of MPMs and their impact on the Libyan emerging market setting. It is found that NFPMs are used to a significant extent by Libyan companies across different industries; however, FPMs are used more widely than NFPMs and MPMs. In other words, Libyan companies tend to rely on traditional (financial) measures much more than multiple measures for evaluating their performance, although respondents were aware of the potential benefits of measurement diversity. The preference for FPMs in Libyan companies can be explained by the high power distance in Libya's conservative society which leads to a preference for performance measures which are underpinned by what are perceived to be hard data. Due to the fact that formal institutions in Libya, and in many other emerging markets, are relatively under developed, there is likely to be less trust in non - financial data, especially that emanating from government, than in traditional, and self-generated, accounting measures.

It is also found that the use of NFPMs and MPMs has a significant positive effect on the performance of Libyan companies but no significant effect was found in the case of FPMs. Measurement diversity is found to have a positive effect on organisational performance; thereby contradicting the findings of a number of earlier studies. Therefore, although there is a preference for FPMs in Libyan organisations, there is a significant pay off arising from the use of NFPMs and MPMs for those organisations which are prepared to use them. That is to say, measurement diversity results in a positive effect on organisational performance.

This study adds to the body of literature which looks at the adoption and deployment of MPMs by investigating the extent to which financial and non-financial measures are used in Libyan companies. The research can therefore be used as a reference point for future work in emerging market contexts. Libya is an under-studied country and one which lacks oft-reported empirical and sample-based evidence. The collection of data from non-manufacturing sectors is a further element of novelty associated with the study since most previous studies, in both developed and emerging market contexts, have focused on manufacturing companies. The study assists 
researchers to investigate the use of FPMs, NFPMs and MPMs in other emerging market contexts

This research has limitations that could be addressed in future studies. In particular, the study did not investigate the impact of each category of the measurement diversity approach (e.g. customer measures, innovation measures, etc.) on organisational performance; in turn, it also did not consider the impact of the identified contingencies on each category of measurement diversity approach. Rather, it focused on the three main categories of the measurement diversity approach; namely, FPMs, NFPMs and MPMs. Therefore, future research could evaluate these individual relationships in order to gain a deeper understanding and provide explanations for these issues.

The evaluation of organisational performance by a self-rating scale is subject to criticism in terms of validity or reliability (Abernethy and Guthrie, 1994), but most relevant literature uses this approach (e.g. Chong and Chong, 1997; Hoque, 2004, 2005; Jusoh and Parnell, 2008). Thus, the search for adequate methods and manners (e.g. archival data, records) of tackling such issues could be an interesting avenue for further research. In addition, the current study adopted a cross-sectional design (i.e. it was conducted at one point in time and did not show the use of performance measures over time) to investigate the cause and effect relationships between identified research variables via regression analyses. Future research should evaluate these causal relationships through longitudinal field research methods, to find out whether the interactions among the contingencies, MPMs and performance are consistent over time.

This study was carried out across different industries in Libya (manufacturing and nonmanufacturing). Although the data that was analysed by sector (ie manufacturing versus nonmanufacturing), the assessment of research hypotheses was based on the results for the whole sample (different industries). This means that in the final sample some industries might be more represented than others. For example, there were a greater proportion of companies operating in a non-manufacturing sector compared to those operating in manufacturing. Therefore, caution is required in generalising the results of this research. Thus the search for an approach to address such problems could be an interesting avenue for further research. 
The study has managerial implications in that it identifies the measures which might assist Libyan companies to develop and improve suitable performance measurement systems to reach their strategic goals. It also enables practitioners to develop performance measurement systems which are conducive to the achievement of the strategic objectives of Libyan firms.

In particular, the findings indicate that Libyan companies should be encouraged to use a diversity of performance measures, particularly non-financial measures which focus on customers, employees, innovation and the environment, in order to enhance the loyalty of customers and attract new ones as well as to serve the other needs of their stakeholders. These implications may also be applicable in other emerging market contexts. However the results of future research may inform this possibility. 


\section{References}

Abdelzaher, D., Latheef, Z. and Abdelzaher, A. 2017. "Recovering from conflict and uncertainty post Arab Spring: A model leveraging employees' spiritual values." International Journal of Conflict Management, Vol.28 No.2, pp. 222-244, https://doi.org/10.1108/IJCMA-02-2016-0005

Abernethy, M. A., and Guthrie, C. H. 1994. "An empirical assessment of the 'fit' between strategy and management information system design." Accounting and Finance, Vol.34 No.2, pp. 49-66.

Abidi, H., Leeuw, S. and Klumpp, M. 2014. "Humanitarian supply chain performance management: a systematic literature review." Supply Chain Management: An International Journal, Vol.19 No.5/6, pp.592-608, https://doi.org/10.1108/SCM-09-2013-0349

Abusa, F. M. and Gibson, P. 2013. "TQM implementation in developing countries: A case study of the Libyan industrial sector." Benchmarking: An International Journal, Vol.20 No.5, pp.693-711, https://doi.org/10.1108/BIJ-01-2012-0003

Agyei-Mensah, B. K. 2017. "Divisional performance measurement in the retail financial service sector: An empirical study." International Journal of Productivity and Performance Management, Vol.66 No.2, pp.180-195, https://doi.org/10.1108/IJPPM-09-2015-0137

Ahmad, M. M. and Elhuni, R. 2014. "Critical quality factors for successful TQM implementation in Libyan oil and gas sector." Benchmarking: An International Journal, Vol.21 No.5, pp.713-733, https://doi.org/10.1108/BIJ-06-2012-0045

Ahmad, N. S. M., and Mousa, R. F. 2010. "Corporate Environmental Disclosure in Libya: A Little Improvement." World Journal of Entrepreneurship, Management and Sustainable Development, Vol.6, No.1/2, pp.149-159.

Akgun, A., Ince, H., Imamoglu, S., and Keskin, H. 2014. "The mediatory role of learning capability and business innovativeness between total quality management and financial performance." International Journal of Production Research, Vol.52, No.3, pp.888-901.

Al Sawalqa, F. A. 2011. The changing role of management accounting: an assessment of the impact of financial and non-financial performance measures usage on organizational performance in Jordan. Unpublished Ph.D Thesis, Murdoch University, Australia.

Al-Rasheed, A. 2001. "Features of Traditional Arab Management and Organization in the Jordan Business Environment", Journal of Transitional Management Development, Vol.6 No.1, pp.27-53. Alvi, F.H. 2012. "Rethinking the institutional context of emerging markets through metaphor analysis", Management International Review, Vol.52 No.4, pp.519-539.

Andrews, D. H., and Wulfeck, W. H. 2014. "Performance assessment: something old, something new". Handbook of Research on Educational Communications and Technology, Springer, pp.303310.

Andrews, R., and S. van de Walle. 2013. "New Public Management and Citizens' Perceptions of Local Service Efficiency, Responsiveness, Equity and Effectiveness". Public Management Review Vol.15 No.5, pp.762-783. doi:10.1080/14719037.2012.725757.

Androwis, N., Sweis, R. J., Tarhini, A., Moarefi, A. and Amiri, M. H. 2018. "Total quality management practices and organizational performance in the construction chemicals companies in Jordan." Benchmarking: An International Journal, Vol.25 No.8, pp.3180-3205, https://doi.org/10.1108/BIJ-05-2017-0094

Anil, A. P. and Satish K.P., (2019) "TQM practices and its performance effects - an integrated model", International Journal of Quality \& Reliability Management, https://doi.org/10.1108/IJQRM-10-2018-0266

Asiaei, K., and Jusoh, R. 2014. "Determinants of performance measurement practices: towards a contingency framework". International Journal of Management Excellence, Vol.2 No.3, pp.257-269. Bakker, K., Boonstra, A., and Wortmann, H. 2014. "The communicative effect of risk identification on project success." Project Organisation and Management, Vol.6 No.1-2, pp.138-156.

Beitelmal, W., Molenaar, K. R., Javernick-Will, A. and Pellicer, E. 2017. "Challenges and barriers to establishing infrastructure asset management: A comparative study between Libya and the USA." Engineering, Construction and Architectural Management, Vol.24 No.6, pp.1184-1202, https://doi.org/10.1108/ECAM-12-2015-0200

Bento, A., and White, L. 2010. "An exploratory study of strategic performance measurement systems." Advances in Management Accounting, Vol.18, pp.1-26. 
Booth, R. 1997. "Performance management: making it happen." Management Accounting (UK), Vol.75 No.10, pp.28-30.

Bourne, M., Mills, J., Wilcox, M., Neely, A., and Platts, K. 2000. "Designing, implementing and updating performance measurement systems." International Journal of Operations and Production Management, Vol.20 No.7, pp.754-771.

Bourne, M., Pavlov, A., Franco-Santos, M., Lucianetti, L. and Mura, M. 2013. "Generating organisational performance." International Journal of Operations \& Production Management, Vol.33 No.11/12, pp.1599-1622.

Braam, G.J.M., and Nijssen, E.J. 2004. "Performance effects of using the Balanced Scorecard: a note on the Dutch experience." Long Range Planning, Vol.37 No.4, pp.335-349.

Brooks, W. K., and Coleman, G. D. 2003. "Evaluating key performance indicators used to drive contractor behavior at AEDC." Engineering Management Journal. Vol.15 No.4, pp.29-39.

Brouthers, K. D. 2013. "Institutional, cultural and transaction cost influences on entry mode choice and performance." Journal of International Business Studies. Vol.44 No.1, pp.1-13.

Bryant, L., Jones, D., and Eidener, S. 2004. "Managing value creation within the firm: an examination of multiple performance measures." Journal of Management Accounting Research, Vol.16 No.1, pp. 107-131.

Burgess, T., Ong, T., and Shaw, N. 2007. "Traditional or contemporary? The prevalence of performance measurement system types." International Journal of Productivity and Performance Management, Vol.56 No.7, pp.583-602.

Busco, C. and Quattrone, P. 2015. "Exploring how the balanced scorecard engages and unfolds: articulating the visual power of accounting inscriptions." Contemporary Accounting Research, Vol.32 No.3, pp.1236-1262.

Chatha, K.A. and Butt, I. 2015. "Themes of study in manufacturing strategy literature." International Journal of Operations \& Production Management, Vol.35 No.4, pp.604-698.

Chenhall, R. 1997. "Reliance on manufacturing performance measures, total quality management and organizational performance." Management Accounting Research, Vol.8 No.2, pp.187-206.

Chenhall, R. 2003. "Management control systems design within its organizational context: findings from contingency-based research and directions for the future." Accounting, Organizations and Society, Vol.28 No.2-3, pp.127-168.

Chenhall, R. H., and Langfield-Smith, K. 1998. "The relationship between strategic priorities, management techniques and mangement accounting: an empirical investigation using a systems approach." Accounting, Organizations and Society, Vol.23 No.3, pp.243-264.

Chenhall, R., and Langfield-Smith, K. 2007. "Multiple perspectives of performance measures." European Management Journal, Vol.25, No.4, pp. 266-282.

Chiwamit, P., Modell, S. and Yang, C. L. 2014. "The societal relevance of management accounting innovations: economic value added and institutional work in the fields of Chinese and Thai stateowned enterprises." Accounting and Business Research, Vol.44 No.2, pp.144-180.

Chong, V. K., and Chong, K. M. 1997. "Strategic choices, environmental uncertainty and SBU performance: a note on the intervening role of management accounting systems." Accounting and Business Research, Vol.27 No.4, pp.268-276.

De Toni, A., and Tonchia, S. 2001. "Performance measurement system: models, characteristics and measures." International Journal of Operations and Production Management, Vol.21 No.1-2, pp. 46-70.

Dikova, D., Sahib,P.R. and van Witteloostuijn,A. 2010. "Cross- border acquisition abandonment and completion: the effect of institutional differences and organisational learning in the international business service industry, 1981-2001." Journal of International Business Studies, Vol.41 No.2, pp. 223-245.

Djankov, S. and Murrell, P. 2002. "Enterprise restructuring in transition: a quantitative survey." Journal of Economic Literature. Vol.40 No.3, pp.739-732.

Dossi, A. and Patelli, L. 2010. "You learn from what you measure: financial and non-financial performance measures in multinational companies." Long Range Planning. Vol.43 No.4, pp. 498 526. 
Dusterhoff, C., Cunningham, J., and MacGregor, J. 2013. "The effects of performance rating, leadermember exchange, perceived utility and organisational justice on performance appraisal satisfaction: applying a moral judgment perspective." Journal of Business Ethics, Vol.119 No.2 pp. 265-273.

Elbanna, S., R. Andrews, and R. Pollanen. 2015. "Strategic Planning and Implementation Success in Public Service Organizations: Evidence from Canada. Public Management Review." Advance online publication. doi:10.1080/14719037.2015.1051576.

Elkrghli S. 2017. "The Relationship between Political Conflict (2013/2016) and Marketing Performances of Libyan Tourism SMEs." Journal of Economics and Business Studies, Vol.6 No.1, pp. 1-16.

Elnihewi, I.M., Mohamed, R. and Hanim, F. 2017. "Contextual factors of performance measurement systems design in Libyan commercial banks". Journal of Advanced Research in Business and Management Studies. Vol.7, No.2, pp.13-28.

Eshtaiwi, M., Badi, I., Abdulshahed, A. and Erkan, T. 2018. "Determination of key performance indicators for measuring airport success: A case study in Libya". Journal of Air Transport Management, Vol. 68, pp.28-34.

Evans, J. R. 2004. "An exploratory study of performance measurement systems and relationships with performance results." Journal of Operations Management, Vol.22 No.3, pp.219-232.

Fakhri, G. 2010. The analysis of the factors affecting performance measurement in the Libyan banking industry: a contingency approach. Unpublished Ph.D. Thesis. Liverpool John Moores University, UK.

Fakhri, G., Menacere, K. and Pegum, R. 2009. "The Impact of Contingent Factors on the Use of Performance Measurement System in the Banking Industry: The Case of Libya." Salford Postgraduate Annual Research Conference, Salford, May 7th -8th 2009.

Field, A. 2005. Discovering statistics using SPSS (2 ${ }^{\text {nd }}$ ed.). London: Sage Publications.

Fleming, D. M., Chow, C. W., and Chen, G. 2009. "Strategy, performance-measurement systems, and performance: a study of Chinese firms." International Journal of Accounting, Vol.44 No.3, pp.256-278.

Franco-Santos, M. 2007. The performance impact of using measurement diversity in executives' annual incentive systems. Unpublished Ph.D Thesis, Cranfield University, UK.

Franco-Santos, M., L. Lucianetti, and M. Bourne. 2012. "Contemporary Performance Measurement Systems: A Review of their Consequences and a Framework for Research." Management Accounting Research Vol.23 No.2, pp.79-119. doi:10.1016/j.mar.2012.04.001.

Garengo, P., and Sharma, M. K. 2014. "Performance measurement system contingency factors: a cross analysis of Italian and Indian SMEs." Production Planning and Control, Vol.25 No.3, pp. 220240.

Geanuracos, J., and Meiklejohn, I. 1993. Performance measurement: the new agenda. London: Business Intelligence.

Gharbal, N., Sagoo, A. and Shibani, A. 2014. "Critical quality factors and financial performance of the Libyan construction firms." Proceedings of the 2014 International Conference on Industrial Engineering and Operations Management. Bali, Indonesia.

Gómez-Bezares, F., Przychodzen, W. and Przychodzen, J. 2017. "Bridging the gap: How sustainable development can help companies create shareholder value and improve financial performance". Business Ethics: a European Review, Vol.26 No.1, pp.1-17.

Gosselin, M. 2005. "An empirical study of performance measurement in manufacturing firms." International Journal of Productivity and Performance Management, Vol.54 No.5-6, pp.419-437.

Govindarajan, V. 1984. "Appropriateness of accounting data in performance evaluation: an empirical examination of environmental uncertainty as an intervening variable." Accounting, Organizations and Society, Vol.9 No.2, pp.125-135.

Govindarajan, V. and Gupta, A.K. 1985. "Linking control-systems to business unit strategy - impact on performance." Accounting, Organisations and Society, Vol.10 No.1, pp.51-66.

He, C. and Lu, K. 2018. "Risk management in SMEs with financial and non-financial indicators using business intelligence methods." Technology, Innovation and Industrial Management conference 16-18 May 2018 Naples, Italy.

Henri, J. 2004. "Performance measurement and organizational effectiveness: bridging the gap." Managerial Finance, Vol.30 No.6, pp.93-123. 
Henri, J. 2006. "Organizational culture and performance measurement systems." Accounting, Organizations and Society, Vol.31 No.1, pp.77-103.

Ho, J. L. Y., Wu, A. and Wu, S. Y. C. 2014. "Performance measures, consensus on strategy implementation and performance: evidence from the operational-level of organisations." Accounting, Organisations and Society, Vol.39 No.1, pp. 38-58.

Hofstede, G., Hofstede, G.J., and Minkov, M. 2010, Cultures and Organizations: Software of the Mind, New York; McGraw Hill.

Homburg, C., Artz, M. and Wieseke, J. 2012, "Marketing performance measurement systems: does comprehensiveness really improve performance?", Journal of Marketing, Vol.76 No.3, pp.56-77. Hoque, Z. 2004. "A contingency model of the association between strategy, environmental uncertainty and performance measurement: impact on organisational performance." International Business Review, Vol.13 No.4, pp.485-502.

Hoque, Z. 2005. "Linking environmental uncertainty to non-financial performance measures and performance: a research note." British Accounting Review, Vol.37 No.4, pp.471-481.

Horenbeek, A. V. and Pintelon, L. 2014. "Development of a maintenance performance measurement framework - using the analytic network process (ANP) for maintenance performance indicator selection." International Journal of Management Science, Vol.42 No.1, pp. 33-46.

Hosskisson, R. E., Wright, M., Filatochev, I. and Peng, M. W. 2013, "Emerging Multinationals from Mid-Range Economies: The Influence of Institutions and Factor Markets." Journal of Management Studies, Vol.50 No.7, pp.1295-1321.

Hussain, N., Rigoni, U. and Cavezzali, E. 2018. "Does it pay to be sustainable? Looking inside the black box of the relationship between sustainability performance and financial performance". Corporate Social Responsibility and Environmental Management, Vol.25 No.6, pp.1198-1211.

Hussain, M. M., and Hoque, Z. 2002. "Understanding non-financial performance measurement practices in Japanese banks: a new institutional sociology perspective." Accounting, Auditing and Accountability Journal, Vol.15 No.2, pp. 162-183.

Hussey, J., and Hussey, R. 1997. Business research: a practical guide for undergraduate and postgraduate students. Macmillan Press Ltd.

Hutaibat, K. A. 2005. Management accounting practices in Jordan: a contingency approach. Unpublished Ph.D Thesis, University of Bristol, Bristol, UK.

Iles, P., Almhedie, A. and Baruch, Y. 2012. "Managing HR in the Middle East: challenges in the public sector." Public Personnel Management, Vol.41 No.3, pp. 465-492.

Imhmed, A. E., Kertahadi, A.M. and Nayati H. 2014. "Utami Job Satisfaction, Organizational Behavior, and Training to Improve Employees Performance Acase: Public Hospitals - Libya." IOSR Journal of Business and Management. Vol.16 No.8, pp.75-82.

Ismail, T. 2007. "Performance evaluation measures in the private sector: Egyptian practice." Managerial Auditing Journal, Vol.22 No.5, pp.503-513.

Ittner, C., and Larcker, D. 1998a. "Are non-financial measures leading indicators of financial performance? An analysis of customer satisfaction." Journal of Accounting Research, Vol.36 No.3, pp.1-35.

Ittner, C., and Larcker, D. 1998b. "Innovations in performance measurement: trends and research implications.” Journal of Management Accounting Research, Vol.10 No.1, pp.205-238.

Ittner, C., and Larcker, D. 2001. "Assessing empirical research in managerial accounting: a valuebased management perspective." Journal of Accounting and Economics, Vol.32 No.1-3, pp.349-410. Ittner, C., and Larcker, D. 2003. "Coming up short on non-financial performance measurement." Harvard Business Review, 81(11): 88-95.

Ittner, C., Larcker, D. and Randall, T. 2003. "Performance implications of strategic performance measurement in financial services firms." Accounting, Organizations and Society, Vol.28 No.7/8, pp. 715-741.

Jusoh, R. 2010. "The influence of perceived environmental uncertainty, firm size, and strategy on multiple performance measures usage." African Journal of Business Management, Vol.4 No.10), pp.1972-1984.

Jusoh, R., and Parnell, J. A. 2008. "Competitive strategy and performance measurement in the Malaysian context: an exploratory study.” Management Decision, Vol. 46 No.1, pp. 5-31. 
Kang, W. and Montoya, M. 2014. "The impact of product portfolio strategy on financial performance: the roles of product development and market entry decisions." Journal of Product Innovation Management, Vol.31 No.3, pp. 516-534.

Kasperskaya, Y. and Tayles, M. 2013. "The role of causal links in performance measurement models." Managerial Auditing Journal, Vol.28 No.5, pp.426-443.

Kennerley, M., and Neely, A. 2002. "A framework of the factors affecting the evolution of performance measurement systems." International Journal of Operations and Production Management, Vol.22 No.11, pp.1222-1245.

Khanna, T. and Palepu, K. 2000. "The future of business groups in emerging markets: long run evidence from Chile." Academy of Management Journal, Vol.43 No.3, pp. 268-285.

Kim, M. and Pennington-Gray, L. 2017. "Does franchisor ethical value really lead to improvements in financial and non-financial performance?," International Journal of Contemporary Hospitality Management, Vol.29 No.10, pp. 2573-2591, https://doi.org/10.1108/IJCHM-04-2016-0188

Koufteros, X., Verghese, A., and Lucianetti, L. 2014. "The effect of performance measurement systems on firm performance: a cross sectional and a longitudinal study." Journal of Operations Management, Vol.32 No.6, pp. 313-336.

Lau, C. M. and Roopnarain, K. 2014. "The effects of nonfinancial and financial measures on employee motivation to participate in target setting." British Accounting Review, Vol.46 No.3, pp.228-247.

Li, S., Ngniatedema, T. and Chen, F. 2017. "Understanding the Impact of Green Initiatives and Green Performance on Financial Performance in the US". Business Strategy and the Environment, Vol.26 No.6, pp.776-790.

Liguori, M., M. Sicilia, and I. Steccolini. 2012. "Some Like It Nonfinancial. . .Politicians' and Managers' Views on the Importance of Performance Information." Public Management Review. Vol.14 No.7, pp.903-922. doi:10.1080/14719037.2011.650054.

Lopes, I. S., Sousa, S. D., Nunes, E. (2016) "Methodology for uncertainty characterization of performance measures", International Journal of Quality \& Reliability Management, Vol. 33 No. 9, pp.1346-1363, https://doi.org/10.1108/IJQRM-10-2014-0146

Luft, J., and Shields, M. 2002. "Zimmerman's contentious conjectures: describing the present and prescribing the future of empirical management accounting research." European Accounting Review, Vol.11 No.4, pp.795-803.

MacBryde, J., Paton, S., Bayliss, M., and Grant, N. 2014. "Transformation in the defence sector: the critical role of performance measurement." Management Accounting Research, Vol.25 No.2, pp. 157-172.

Maletic, M., Maletic, D., Dahlgaard, J.J., Dahlgaard-Park, S.M. and Gomiscek, B. 2015. "Effect of sustainability-oriented innovation practices on the overall organizational performance: an empirical examination," Total Quality Management \& Business Excellence, Vol.27 No.9-10, pp.1171-1190.

Marefat, D. and Faridfathi, A. 2015, "Relationship between information technology and total quality management in sport federations," Journal of Applied Environmental and Biological Sciences, Vol.5 No.3, pp. 52-58.

Marr, B., and Schiuma, G. 2003. "Business performance measurement-past, present and Future." Management Decision, Vol.41 No.8, pp.680-687.

Medori, D., and Steeple, D. 2000. "A framework for auditing and enhancing performance measurement systems." International Journal of Operations and Production Management, Vol.20 No.5, pp. 520-533.

Meier, K. J. and L. J. O'Toole. 2013. "Subjective organizational performance and measurement error: common source bias and spurious relationships", Journal of Public Administration Research and Theory, Vol. 23, pp. 429-456.

Melnyk, S.A., Bititci, U., Platts, K., Tobias, J. and Andersen, B. 2014. "Is performance measurement and management fit for the future?", Management Accounting Research, Vol.25 No.2, pp. 173-186. Mia, L., and Clarke, B. 1999. "Market competition, management accounting systems and business unit performance." Management Accounting Research, Vol.10 No.2, pp. 137-58.

Mia, L., and Winata, L. 2008. "Manufacturing strategy, broad scope MAS information and information and communication technology." British Accounting Review, Vol.40 No.2, pp.182-192. 
Michalski, G. 2014. "Value maximising corporate current assets and cash management in relation to risk sensitivity: Polish firms' case." Wroclaw University of Economics.

Micheli P. and Mura, M. 2017. "Executing strategy through comprehensive performance measurement systems," International Journal of Operations \& Production Management, Vol.37 No.4, pp. 423-443, https://doi.org/10.1108/IJOPM-08-2015-0472

Mintz, O. and Curim, I. S. 2013. "What drives managerial use of marketing and financial metrics and does metric use affect performance of marketing-mix activities?" Journal of Marketing, Vol.77 No.2, pp. $17-40$.

Musbah, A., Cowton, C.J. and Tyfa, D. 2016. "The Role of Individual Variables, Organizational Variables and Moral Intensity Dimensions in Libyan Management Accountants' Ethical Decision Making." Journal of Business Ethics. Vol.134, pp.335-358. https://doi.org/10.1007/s10551-014$\underline{2421-3}$

Nawaz, T. and Haniffa, R. 2017. "Determinants of financial performance of Islamic banks: an intellectual capital perspective, Journal of Islamic Accounting and Business Research," Vol.8 No.2, pp. 130-142, https://doi.org/10.1108/JIABR-06-2016-0071

Neely, A. 2008. Does the Balanced Scorecard work; an empirical investigation. Research Paper Series, Centre for Business Performance, School of Management, Cranfield University (1/08).

Neely, A., Gregory, M., and Platts, K. 1995. "Performance measurement system design: a literature review and research agenda." International Journal of Operations and Production Management, Vol.15 No.4, pp.80-116.

North, D. C. 1990. Institutions, institutional change and economic performance, Cambridge, Massachusetts: Harvard University Press.

O'Connell, V. and O'Sullivan, D. 2014. "The influence of lead indicator strength on the use of nonfinancial measures in performance management: evidence from CEO compensation schemes." Strategic Management Journal, Vol.35 No.6, pp. 826-844.

Pargeter, A. 2012. Libya: the rise and fall of Qaddafi, New Haven:Yale University Press.

Peasnell, K., 1993. "Guest editorial: accounting in developing countries the search for appropriate technologies." Research in Third World Accounting, Vol.2, pp.1-16.

Peng, M. W. 2003. "Institutional transitions and strategic choices," Academy of Management Review, Vol.28 No.2, pp. 275-296.

Pinho, J. C., Rodrigues, A. P., and Dibb, S. 2014. "The role of corporate culture, market orientation and organisational commitment in organisational performance: the case of non-profit organisations." Journal of Management Development, Vol.33 No.4, pp. 374-398.

Pollanen, R., Abdel-Maksoud, A., Elbanna, S. and Mahama H. 2017. "Relationships between strategic performance measures, strategic decision-making, and organizational performance: empirical evidence from Canadian public organizations," Public Management Review, Vol.19 No. 5, pp. 725-746, DOI: 10.1080/14719037.2016.1203013

Porter, M.E. 1980. Competitive Strategy: Techniques for Analyzing Industries and Competitors, The Free Press, New York, NY.

Posthuma, R.A. 2011. Conflict management in the middle east, International Journal of Conflict Management, Vol.22 No.3, pp.216-218.

Salleh, N., Jusoh, R., and Isa, C. 2010. "Relationship between information systems sophistication and performance measurement." Industrial Management and Data Systems, Vol.110 No.7, pp. 9931017.

Santos S. P., Belton V. and Howick S. 2012. "Adding value to performance measurement by using system dynamics and multiple criteria analysis." International Journal of Operations and Production Management, Vol.22 No.11, pp. 1246-1272.

Saunila, M., Rantala, T., Ukko, J. and Pekkola, S. (2017) "Gaining insights into the measurement of value in industrial service network", International Journal of Quality \& Reliability Management, Vol. 34 No. 4, pp.478-493, https://doi.org/10.1108/IJQRM-03-2015-0046

Scarpin, M. and Brito, L. (2018) "Operational capabilities in an emerging country: quality and the cost trade-off effect", International Journal of Quality \& Reliability Management, Vol. 35 No. 8 , pp.1617-1638, https://doi.org/10.1108/IJQRM-04-2017-0061 
Scott, T., and Tiessen, P. 1999. "Performance measurement and managerial teams." Accounting, Organizations and Society, Vol.24 No.3, pp. 263-285.

Singh, S.,Darwish,T.K.and Potocnik 2016. "Measuring Organizational Performance: A Case for Subjective Measures." British Journal of Management, Vol.27 No.1, pp. 214-224.

Stålberg, L. and Fundin, A. (2016) "Exploring a holistic perspective on production system improvement", International Journal of Quality \& Reliability Management, Vol. 33 No. 2, pp.267283, https://doi.org/10.1108/IJQRM-11-2013-0187

Tangen, S. 2005. I"nsights from practice Analysing the requirements of performance measurement systems." Measuring Business Excellence, Vol.9 No.4, pp.46-54.

Thorne, H. 1995. "Performance measures in manufacturing: lessons from the Balanced Scorecard and Dynamic model." Accounting Forum, Vol.18 No.4, pp.27-44.

Tjader, Y., May, J. H., Shang, J., Vargas, L. G. and Gao, N. 2014. "Firm-level outsourcing decision making: a balanced scorecard-based analytic network process model." International Journal of Production Economics, Vol.147 No.C, pp. 614-623.

Upadhaya, B., Munir, R. and Blount, Y. 2014. "Association between performance measurement systems and organisational effectiveness." International Journal of Operations \& Production Management, Vol.34 No.7, pp. 853-875.

Vallurupalli, V. and Bose, I. 2018. "Business intelligence for performance measurement: A case based analysis". Decision Support Systems, Vol. 111, pp.72-85.

Van der Stede, W. A., Chow, C. W., and Lin, T. W. 2006. "Strategy, choice of performance measures, and performance." Behavioral Research in Accounting, Vol.18 No.1, pp.185-205.

Verbeeten, F.H.M. and Boons, A. N.A.M 2009. "Strategic priorities, performance measures and performance: an empirical analysis in Dutch firms." European Management Journal, Vol.27 No.2, pp.113-128.

Wei, Y. Samiee, S. and Lee, R. P. 2014. "The influence of organic organisational cultures, market responsiveness, and product strategy on firm performance in an emerging market." Journal of the Academy of Marketing Science, Vol.42 No.1, pp. 49-70.

Wellens, L. and Jegers, M. 2014." Effective governance in nonprofit organisations: a literature based multiple stakeholder approach.” European Management Journal, Vol.32 No.2, pp.223-243.

Wright, M., Filatochev, I., Hoskisson, R.E. and Peng, M.W. 2005. "Strategy research in emerging economies: challenging the conventional wisdom." Journal of Management Studies, Vol.42 No.1, pp.1-33.

Wu, J. 2013. "Diverse institutional environments and product innovation of emerging market firms", Management International Review, Vol.53 No.1, pp.39-59.

$\mathrm{Wu}, \mathrm{W}$. and Liao, Y. 2014. "A balanced scorecard envelopment approach to assess airlines' performance." Industrial Management and Data Systems, Vol.114 No.1, pp.123-143.

Yaghi, B. 2007. The moderating effects of performance measurement use on the relationship between organizational performance measurement diversity and product innovation. Unpublished $\mathrm{Ph} . \mathrm{D}$ Thesis, Cranfield University, UK.

Yongvanich, K., and Guthrie, J. 2009. "Balanced Scorecard practices amongst Thai companies: performance effects." Pacific Accounting Review, Vol.21 No.2, pp.132-149.

Youssef, A. E. 2007. The contingent factors that affect the use of performance measurement systems in Egyptian medium and large sized manufacturing companies. Unpublished Ph.D Thesis, University of Durham, UK.

Yuliansyah Y., Gurd, B. and Mohamed, N. 2017. "The significant of business strategy in improving organizational performance." Humanomics, Vol.33 No.1, pp. 56-74, https://doi.org/10.1108/H-062016-0049

Zuriekat, M. I. 2005. Performance measurement systems: an examination of the influence of the contextual factors and their impact on performance with a specific emphasis on the balanced scorecard approach. Unpublished Ph.D. Thesis, University of Huddersfield, UK. 


\section{Tables}

Table 1: Frequency Distribution of Characteristics of Respondents

\begin{tabular}{|c|c|c|c|c|c|c|}
\hline \multirow{2}{*}{$\begin{array}{r}\text { Items } \\
\text { Job Title }\end{array}$} & \multicolumn{2}{|c|}{$\begin{array}{c}\text { Manufacturing } \\
(N=49)\end{array}$} & \multicolumn{2}{|c|}{$\begin{array}{c}\text { Non-manufacturing } \\
(N=83)\end{array}$} & \multicolumn{2}{|c|}{$\begin{array}{c}\text { Both } \\
(N=132)\end{array}$} \\
\hline & Frequency & Per cent & Frequency & Per cent & Frequency & Per cent \\
\hline Financial Manager & 18 & $36.7 \%$ & 40 & $48.2 \%$ & 58 & $43.9 \%$ \\
\hline $\begin{array}{l}\text { Vice-Financial } \\
\text { Manager }\end{array}$ & 12 & $24.5 \%$ & 15 & $18.1 \%$ & 27 & $20.5 \%$ \\
\hline Controller & 7 & $14.3 \%$ & 8 & $9.6 \%$ & 15 & $11.4 \%$ \\
\hline Senior accountant & 9 & $18.4 \%$ & 14 & $16.9 \%$ & 23 & $17.4 \%$ \\
\hline Other & 3 & $6.1 \%$ & 6 & $7.2 \%$ & 9 & $6.8 \%$ \\
\hline Qualification & Frequency & Per cent & Frequency & Per cent & Frequency & Per cent \\
\hline Secondary & 2 & $4.1 \%$ & 2 & $2.4 \%$ & 4 & $3 \%$ \\
\hline Diploma & 6 & $12.2 \%$ & 3 & $3.6 \%$ & 9 & $6.8 \%$ \\
\hline Bachelor & 25 & $51 \%$ & 48 & $57.8 \%$ & 73 & $55.3 \%$ \\
\hline Post-graduate & 11 & $22.5 \%$ & 19 & $22.9 \%$ & 30 & $22.7 \%$ \\
\hline Other & 5 & $10.2 \%$ & 11 & $13.3 \%$ & 16 & $12.1 \%$ \\
\hline Subject & Frequency & Per cent & Frequency & Per cent & Frequency & Per cent \\
\hline Accounting & 21 & $42.9 \%$ & 40 & $48.2 \%$ & 61 & $46.2 \%$ \\
\hline Business Management & 6 & $12.2 \%$ & 10 & $12.1 \%$ & 16 & $12.1 \%$ \\
\hline Finance & 15 & $30.6 \%$ & 23 & $27.7 \%$ & 38 & $28.8 \%$ \\
\hline Economy & 3 & $6.1 \%$ & 2 & $2.4 \%$ & 5 & $3.8 \%$ \\
\hline Other & 4 & $8.2 \%$ & 8 & $9.6 \%$ & 12 & $9.1 \%$ \\
\hline \multicolumn{7}{|c|}{ Experience } \\
\hline \multirow[t]{2}{*}{ Items } & \multicolumn{2}{|c|}{$\begin{array}{l}\text { Experience } \\
\text { (in the Job) }\end{array}$} & \multicolumn{2}{|c|}{$\begin{array}{c}\text { Experience } \\
\text { (in the company) }\end{array}$} & \multicolumn{2}{|c|}{ Full experience } \\
\hline & Frequency & Per cent & Frequency & Per cent & Frequency & Per cent \\
\hline Less than 5 years & 18 & $13.6 \%$ & 14 & $10.6 \%$ & 7 & $5.3 \%$ \\
\hline $5-10$ years & 33 & $25 \%$ & 36 & $27.3 \%$ & 16 & $12.1 \%$ \\
\hline $10-15$ years & 41 & $31.1 \%$ & 27 & $20.5 \%$ & 25 & $18.9 \%$ \\
\hline $15-20$ years & 23 & $17.4 \%$ & 24 & $18.2 \%$ & 38 & $28.8 \%$ \\
\hline 20 years or more & 17 & $12.9 \%$ & 31 & $23.5 \%$ & 46 & $34.8 \%$ \\
\hline
\end{tabular}

Table 2: Frequency Distribution of Characteristics of Respondent Companies

\begin{tabular}{|c|c|c|c|c|c|c|}
\hline \multirow{2}{*}{$\begin{array}{r}\text { Items } \\
\text { Company age }\end{array}$} & \multicolumn{2}{|c|}{$\begin{array}{c}\text { Manufacturing } \\
(N=49)\end{array}$} & \multicolumn{2}{|c|}{$\begin{array}{c}\text { Non-manufacturing } \\
(\mathrm{N}=83)\end{array}$} & \multicolumn{2}{|c|}{$\begin{array}{c}\text { Both } \\
(N=132)\end{array}$} \\
\hline & Frequency & Per cent & Frequency & Per cent & Frequency & Per cent \\
\hline Less than 5 years & 3 & $6.1 \%$ & 4 & $4.8 \%$ & 7 & $5.3 \%$ \\
\hline $5-10$ years & 4 & $8.2 \%$ & 7 & $8.4 \%$ & 11 & $8.3 \%$ \\
\hline $10-15$ years & 4 & $8.2 \%$ & 15 & $18.1 \%$ & 19 & $14.4 \%$ \\
\hline $15-20$ years & 12 & $24.4 \%$ & 20 & $24.1 \%$ & 32 & $24.2 \%$ \\
\hline 20 years or more & 26 & $53.1 \%$ & 37 & $44.6 \%$ & 63 & $47.7 \%$ \\
\hline Type of Business & Frequency & Percent & Frequency & Percent & Frequency & Percent \\
\hline Number of companies & 49 & $37.1 \%$ & 83 & $62.9 \%$ & 132 & $100 \%$ \\
\hline \multicolumn{7}{|c|}{ Company size (CS) } \\
\hline Number of Employees & Frequency & Per cent & Frequency & Per cent & Frequency & Per cent \\
\hline Less than 100 people & 7 & $14.3 \%$ & 34 & $41 \%$ & 41 & $31.1 \%$ \\
\hline 100-250 people & 14 & $28.6 \%$ & 18 & $21.7 \%$ & 32 & $24.2 \%$ \\
\hline $250-500$ people & 10 & $20.4 \%$ & 10 & $120 \%$ & 20 & $15.2 \%$ \\
\hline 500-1000 people & 3 & $6.1 \%$ & 10 & $120 \%$ & 13 & $9.8 \%$ \\
\hline 1000 people or more & 15 & $30.6 \%$ & 11 & $13.3 \%$ & 26 & $19.7 \%$ \\
\hline
\end{tabular}




\begin{tabular}{|l|c|c|c|c|c|c|}
\hline $\begin{array}{l}\text { Annual revenue/sales - } \\
\text { LD }\end{array}$ & Frequency & Per cent & Frequency & Per cent & Frequency & Per cent \\
\hline Less than 1 million & $\mathbf{8}$ & $\mathbf{1 6 . 3} \%$ & $\mathbf{3 1}$ & $\mathbf{3 7 . 3} \%$ & $\mathbf{3 9}$ & $\mathbf{2 9 . 5} \%$ \\
\hline $1 \mathrm{~m}-5 \mathrm{~m}$ & $\mathbf{1 7}$ & $\mathbf{3 4 . 7} \%$ & $\mathbf{2 8}$ & $\mathbf{3 3 . 7} \%$ & $\mathbf{4 5}$ & $\mathbf{3 4 . 1} \%$ \\
\hline $5 \mathrm{~m}-10 \mathrm{~m}$ & $\mathbf{5}$ & $\mathbf{1 0 . 2} \%$ & $\mathbf{1 2}$ & $\mathbf{1 4 . 6} \%$ & $\mathbf{1 7}$ & $\mathbf{1 2 . 9} \%$ \\
\hline $10 \mathrm{~m}-15 \mathrm{~m}$ & $\mathbf{3}$ & $\mathbf{6 . 1} \%$ & $\mathbf{4}$ & $\mathbf{4 . 8} \%$ & $\mathbf{7}$ & $\mathbf{5 . 3} \%$ \\
\hline $15 \mathrm{million}$ or more & $\mathbf{1 6}$ & $\mathbf{3 2 . 7} \%$ & $\mathbf{8}$ & $\mathbf{9 . 6} \%$ & $\mathbf{2 4}$ & $\mathbf{1 8 . 2} \%$ \\
\hline Type of ownership & Frequency & $\boldsymbol{P e r}$ cent & Frequency & Per cent & Frequency & Per cent \\
\hline State-owned company & $\mathbf{2 1}$ & $\mathbf{4 2 . 9} \%$ & $\mathbf{2 7}$ & $\mathbf{3 2 . 5} \%$ & $\mathbf{4 8}$ & $\mathbf{3 6 . 4 \%}$ \\
\hline Private company & $\mathbf{1 4}$ & $\mathbf{2 8 . 6} \%$ & $\mathbf{4 1}$ & $\mathbf{4 9 . 4 \%}$ & $\mathbf{5 5}$ & $\mathbf{4 1 . 7} \%$ \\
\hline Joint-venture (State \& foreign ) & $\mathbf{3}$ & $\mathbf{6 . 1} \%$ & $\mathbf{5}$ & $\mathbf{6 . 0} \%$ & $\mathbf{8}$ & $\mathbf{6 . 0} \%$ \\
\hline Joint-venture (State \& private) & $\mathbf{6}$ & $\mathbf{1 2 . 2} \%$ & $\mathbf{4}$ & $\mathbf{4 . 8} \%$ & $\mathbf{1 0}$ & $\mathbf{7 . 6} \%$ \\
\hline Joint-venture (private \& foreign) & $\mathbf{5}$ & $\mathbf{1 0 . 2} \%$ & $\mathbf{6}$ & $\mathbf{7 . 3} \%$ & $\mathbf{1 1}$ & $\mathbf{8 . 3} \%$ \\
\hline
\end{tabular}

* LD: Libyan Dinar. 2.11 LD equals 1 UK pound (Aug. 2012)

Table 3: Descriptive Analysis of Organisational Performance

\begin{tabular}{|c|c|c|c|c|c|c|c|}
\hline \multirow{2}{*}{ Items } & \multicolumn{5}{|c|}{$\%(N=132)$} & \multirow{2}{*}{ Mean } & \multirow{2}{*}{$S . D$} \\
\hline & 1 & 2 & 3 & 4 & 5 & & \\
\hline Net income & 8.3 & 15.9 & 25.0 & 37.1 & 13.6 & 3.318 & 1.148 \\
\hline ROI & 9.1 & 13.6 & 28.0 & 40.2 & 9.1 & 3.265 & 1.097 \\
\hline Revenue/sales growth & 1.5 & 21.2 & 22.0 & 44.7 & 10.6 & 3.417 & .9888 \\
\hline Cost reduction & 2.3 & 26.5 & 23.5 & 36.4 & 11.4 & $3 . .280$ & 1.051 \\
\hline Product/service quality & 1.5 & 22.7 & 16.7 & 41.7 & 17.4 & 3.508 & 1.074 \\
\hline Productivity & 2.3 & 18.9 & 27.3 & 38.6 & 12.9 & 3.409 & 1.011 \\
\hline Customer satisfaction & 2.3 & 16.7 & 24.2 & 45.5 & 11.4 & 3.470 & .9764 \\
\hline Market share & 3.0 & 28.8 & 26.5 & 29.5 & 12.1 & 3.189 & 1.078 \\
\hline Employee satisfaction & 6.1 & 16.7 & 33.3 & 35.6 & 8.3 & 3.235 & 1.025 \\
\hline Research and personnel development & 3.8 & 17.4 & 34.1 & 33.3 & 11.4 & 3.311 & 1.012 \\
\hline New product/service innovation & 5.3 & 21.2 & 33.3 & 28.8 & 11.4 & 3.197 & 1.066 \\
\hline Competitive position & 5.3 & 10.6 & 29.5 & 42.4 & 12.1 & 3.455 & 1.014 \\
\hline Achieving company's strategic aims & 0.0 & 13.6 & 31.8 & 50.0 & 4.5 & 3.455 & .7850 \\
\hline \multicolumn{8}{|c|}{ Dependent Variable (overall) } \\
\hline \multirow{2}{*}{ Organisational performance (OP) } & \multicolumn{2}{|l|}{$\mathrm{N}$} & Min & \multicolumn{2}{|c|}{ Max } & Mean & S.D \\
\hline & \multicolumn{2}{|c|}{132} & 1.62 & \multicolumn{2}{|c|}{5.00} & 3.347 & 0.5580 \\
\hline $1=$ Porr $2=$ J ecs than & & & & & & & \\
\hline
\end{tabular}


Table 4: Reliability Coefficients (Cronbach's Alpha) for Research Variables

\begin{tabular}{|c|l|c|c|}
\hline No & \multicolumn{1}{|c|}{ Research variables } & $\begin{array}{c}\text { Number of } \\
\text { items }\end{array}$ & $\begin{array}{c}\text { Cronbach's } \\
\text { alpha }\end{array}$ \\
\hline 1 & Financial performance measures & 11 & 0.767 \\
\hline 2 & Overall non-financial performance measures & 30 & 0.939 \\
\hline 3 & Multiple performance measures' usage & 41 & 0.919 \\
\hline 4 & Business strategy & 7 & 0.877 \\
\hline 5 & Environmental uncertainty & 7 & 0.654 \\
\hline 6 & Market competition & 6 & 0.785 \\
\hline 7 & Decentralisation & 7 & 0.906 \\
\hline 8 & Formalisation & 5 & 0.728 \\
\hline 9 & Information technology & 10 & 0.862 \\
\hline 10 & Company size (NOE) & 1 & N/A* \\
\hline 11 & Company size (AR) & 1 & N/A* \\
\hline 12 & Organisational performance & 13 & 0.800 \\
\hline \multicolumn{2}{|l|}{ * Not available due to the nature of these variables } \\
\hline
\end{tabular}

Table 5: Relationship between the use of MPMs and Organisational Performance

\begin{tabular}{|c|c|c|c|c|c|}
\hline \multirow{3}{*}{$\begin{array}{c}\text { Variable } \\
\text { (Predictors) }\end{array}$} & \multicolumn{5}{|c|}{ Dependent variable (Organisational performance) } \\
\hline & \multicolumn{2}{|c|}{ Unstand. coefficient } & Stand. coefficient & \multirow{2}{*}{ t-value } & \multirow{2}{*}{ Sig. } \\
\hline & $\boldsymbol{B}$ & Std. Error & Beta & & \\
\hline FPMs' usage & .110 & .090 & .107 & 1.223 & .223 \\
\hline \multicolumn{6}{|c|}{$R=.107, R^{2}=.011$, Adjusted $R^{2}=.004, F$-value $=1.496$, Sig. $=.223$} \\
\hline NFPMs' usage & .365 & .061 & .467 & 6.022 & .000 \\
\hline \multicolumn{6}{|c|}{$R=.467, R^{2}=.218$, Adjusted $R^{2}=.212, F$-value $=36.26$, Sig. $=000$} \\
\hline MPMs' usage (overall) & .477 & .078 & .471 & 6.083 & .000 \\
\hline \multicolumn{6}{|c|}{$R=.471, R^{2}=.222$, Adjusted $R^{2}=.216, F$-value $=37.000$, Sig. $=000$} \\
\hline
\end{tabular}

Table 6: Descriptive Analysis of the Use of MPMs in Libyan Companies

\begin{tabular}{|c|c|c|c|c|c|c|c|}
\hline \multirow{2}{*}{ Items } & \multicolumn{5}{|c|}{$\%(N=132)$} & \multirow{2}{*}{ Mean } & \multirow{2}{*}{ S.D } \\
\hline & 1 & 2 & 3 & 4 & 5 & & \\
\hline Net income & 0.0 & 3.0 & 7.6 & 32.6 & 56.8 & 4.43 & 0.764 \\
\hline Revenue/sales growth & 1.5 & 0.8 & 13.6 & 41.7 & 42.4 & 4.23 & 0.825 \\
\hline ROI (Return on investment) & 1.5 & 3.0 & 15.9 & 34.1 & 45.5 & 4.19 & 0.917 \\
\hline ROA (Return on asset) & 0.8 & 6.8 & 16.7 & 37.1 & 38.6 & 4.06 & 0.947 \\
\hline ROE (Return on equity) & 0.8 & 5.3 & 11.4 & 40.9 & 41.7 & 4.17 & 0.887 \\
\hline ROS (Return on sales) & 1.5 & 1.5 & 17.4 & 33.3 & 46.2 & 4.21 & 0.891 \\
\hline Budgets & 0.0 & 4.5 & 18.2 & 29.5 & 47.7 & 4.20 & $\mathbf{0 . 8 9 7}$ \\
\hline Cash flows & 1.5 & 6.1 & 17.4 & 31.1 & 43.9 & 4.10 & 0.995 \\
\hline Earnings per share (EPS) & 0.8 & 7.6 & 19.7 & 26.5 & 45.5 & 4.08 & 01.01 \\
\hline EVA (Economic value added) & 25.0 & 27.3 & 23.5 & 12.9 & 11.4 & 2.42 & 01.30 \\
\hline Market value added (MVA) & 34.1 & 23.5 & 19.7 & 14.4 & 8.3 & 2.39 & 01.31 \\
\hline \multicolumn{6}{|c|}{ Overall financial perspective-based performance measures } & 3.88 & 0.543 \\
\hline \multicolumn{8}{|c|}{ Non-financial performance measures } \\
\hline Safety & 16.7 & 5.3 & 22.7 & 30.3 & 25.0 & 3.42 & 01.37 \\
\hline Cycle time/lead times (product/service) & 16.7 & 6.1 & 21.2 & 34.1 & 22.0 & 3.39 & $\mathbf{0 1 . 3 5}$ \\
\hline Product/service development & 7.6 & 12.9 & 22.0 & 26.5 & 31.1 & 3.61 & 01.26 \\
\hline Defects rate (product/service) & 12.1 & 8.3 & 17.4 & 29.5 & 32.6 & 3.62 & 01.34 \\
\hline
\end{tabular}




\begin{tabular}{|c|c|c|c|c|c|c|c|c|}
\hline \multicolumn{2}{|r|}{ Product/service quality } & 8.3 & 9.1 & 22.0 & 33.3 & 27.3 & 3.62 & 01.21 \\
\hline \multicolumn{2}{|c|}{ Cost savings } & 10.6 & 12.9 & 14.4 & 32.6 & 29.5 & 3.58 & 01.32 \\
\hline \multicolumn{2}{|c|}{ Productivity } & 8.3 & 8.3 & 15.9 & 41.7 & 25.8 & 3.68 & 01.19 \\
\hline \multicolumn{7}{|c|}{ Overall internal operations perspective-based performance measures } & 3.56 & 1.10 \\
\hline \multicolumn{2}{|c|}{ Market share } & 3.0 & 5.3 & 21.9 & 34.8 & 35.6 & 3.95 & 1.03 \\
\hline \multicolumn{2}{|r|}{ Customer satisfaction } & 2.3 & 3.8 & 12.9 & 48.5 & 32.6 & 4.05 & 0.902 \\
\hline \multicolumn{2}{|c|}{ Customer service } & 12.1 & 3.0 & 18.9 & 40.9 & 25.0 & 3.64 & 1.24 \\
\hline \multicolumn{2}{|r|}{ Number of customer compliances } & 5.3 & 11.4 & 17.4 & 37.9 & 28.0 & 3.72 & 1.15 \\
\hline \multicolumn{2}{|r|}{ Customer retention } & 3.8 & 5.3 & 23.5 & 34.1 & 33.3 & 3.88 & 1.06 \\
\hline \multicolumn{2}{|c|}{ Customer loyalty } & 14.4 & 8.3 & 20.5 & 30.3 & 26.5 & 3.46 & 1.35 \\
\hline \multicolumn{2}{|r|}{ Customer response time } & 9.8 & 6.8 & 20.5 & 43.9 & 18.9 & 3.55 & 1.17 \\
\hline \multicolumn{2}{|r|}{ On-time delivery (product/service) } & 6.1 & 4.5 & 22 & 38.6 & 28.8 & 3.80 & 1.10 \\
\hline \multicolumn{7}{|c|}{ Overall customer perspective-based performance measures } & 3.76 & .819 \\
\hline \multicolumn{2}{|r|}{ Employee satisfaction } & 3.8 & 6.8 & 34.1 & 46.2 & 9.1 & 3.50 & 0.895 \\
\hline \multicolumn{2}{|r|}{ Employee loyalty } & 3.0 & 8.3 & 31.8 & 41.7 & 15.2 & 3.58 & 0.950 \\
\hline \multicolumn{2}{|r|}{ Skills development } & 4.5 & 7.6 & 32.6 & 37.1 & 18.2 & 3.57 & 1.02 \\
\hline \multicolumn{2}{|r|}{ Competitive position } & 5.3 & 7.6 & 31.1 & 41.7 & 14.4 & 3.52 & 1.01 \\
\hline \multicolumn{2}{|r|}{ Research and development activities } & 3.8 & 14.4 & 28.8 & 35.6 & 17.4 & 3.48 & 1.06 \\
\hline \multicolumn{2}{|r|}{ Employee training } & 6.1 & 10.6 & 25.8 & 35.6 & 22.0 & 3.57 & 1.13 \\
\hline \multicolumn{2}{|r|}{ Adapting to changes } & 6.1 & 8.3 & 33.3 & 36.4 & 15.9 & 3.48 & 1.05 \\
\hline \multicolumn{2}{|r|}{ New products/service innovation } & 6.8 & 9.8 & 26.5 & 33.3 & 23.5 & 3.57 & 1.15 \\
\hline \multicolumn{7}{|c|}{ Overall innovation and learning perspective-based performance measures } & 3.53 & .866 \\
\hline \multicolumn{2}{|r|}{$\begin{array}{l}\text { Meeting environmental commitments } \\
\text { (environmentally friendly) }\end{array}$} & 13.6 & 12.1 & 18.9 & 34.1 & 21.2 & 3.37 & 1.32 \\
\hline \multicolumn{2}{|r|}{ Support of charity projects } & 16.7 & 19.7 & 28.8 & 15.9 & 18.9 & 3.01 & 1.34 \\
\hline \multicolumn{2}{|r|}{ Support of social activities } & 13.6 & 25.0 & 25.0 & 20.5 & 15.9 & 3.00 & 1.28 \\
\hline \multicolumn{2}{|r|}{ Community regulations } & 13.6 & 22.7 & 28.8 & 22.7 & 12.1 & 2.43 & 1.22 \\
\hline \multicolumn{2}{|r|}{ Government citations/certification } & 11.4 & 20.5 & 28.8 & 26.5 & 12.9 & 3.09 & 1.20 \\
\hline & $\begin{array}{l}\text { articipation in training and education } \\
\text { Community involvement) }\end{array}$ & 13.6 & 15.2 & 18.9 & 29.5 & 22.7 & 3.33 & 1.35 \\
\hline & ablic image & 8.3 & 14.4 & 12.1 & 27.3 & 37.9 & 3.72 & 1.33 \\
\hline & verall environmental and community & ctive-l & sed pe & rforman & nce meas & ures & 3.21 & 1.01 \\
\hline & & & rall & & & & & \\
\hline & Variables & & & $\mathbf{N}$ & Min & $\operatorname{Max}$ & Mean & S.D \\
\hline 1 & Financial performance measures & & & 132 & 2.00 & 4.91 & 3.88 & 0.543 \\
\hline 2 & Non-financial performance measu & PMs) & & 132 & 1.13 & 4.90 & 3.52 & 0.713 \\
\hline 3 & Multiple performance measures ( & 1 and & & 132 & 1.83 & 4.68 & 3.62 & 0.551 \\
\hline
\end{tabular}

